\title{
POSSIBLE MEANS OF ESCAPE FOR EVACUATION FROM DANGEROUS LOCATIONS VS. THE SAFETY OF THE OCCUPANTS OF THESE PLACES. SOCIOLOGICAL ANALYSIS ON THE EXAMPLE STUDENT SURVEY AT THE RZESZÓW UNIVERSITY OF TECHNOLOGY
}

\begin{abstract}
The aim of this paper is to analyse Rzeszów University of Technology students' familiarity with the emergency exits in the buildings where they attend classes and their knowledge of the evacuation routes from these buildings in the event of a construction disaster, fire, terrorist attack, or other possibly dangerous phenomenon. The analyses described are based on scientific research carried out on a population of 249 university students, to whom a survey regarding this subject was administered. Study findings indicated that respondents' familiarity with emergency exit locations in buildings and knowledge of emergency evacuation procedures for public utility buildings were at a very low level. It is therefore recommended that efforts aimed at ensuring student preparedness should evacuation from university buildings be necessary be increased and that university threat alert systems be improved.
\end{abstract}

Keywords: evacuation from buildings, emergency exits, sociological research, disaster, fire, terrorist attack.

\section{INTRODUCTION}

Considering the existence of broadly understood natural and social disasters occurring in the modern society, there is a necessity to analyze the problem of evacuation from

${ }^{1}$ Eugeniusz Moczuk, Associate Prof. in the Department of Humanities and Social Studies at the Rzeszow University of Technology, e-mail: e.moczuk@prz.edu.pl (corresponding author). ORCID: 0000-0002-5447-6966.

${ }^{2}$ Larisa Fedoniuk, Prof. DSc, PhD. Medical Biology Department. I. Horbachevsky Ternopil National Medical University (Ukraine). ORCID: 0000-0003-4910-6888.

${ }^{3}$ Artur Polakiewicz, MA in the Department of Humanities and Social Studies at the Rzeszow University of Technology, e-mail: polakiewicz@ prz.edu.pl. ORCID: 0000-0002-5999-8202.

4 Arkadiusz Leśniak-Moczuk, MA in the Faculty of Law at University of Bialystok. ORCID: 0000$-0001-7758-5519$. 
emergency sites, especially when there is a possibility to prepare and plan for emergency. It is important to indicate that the aforementioned issue is the domain of safety sciences, which, in turn, covers problems of crisis management and health and safety.

In broad terms, emergency evacuation is an urgent displacement of people away from an area that contains an imminent threat, an ongoing threat or a hazard to lives or property to safer locations. In narrow terms, in turn, it movement of people away from locations affected by specific single disasters, such as fire, floods, earthquakes, tsunami or even wars. Typical elements of an evacuation process is its planning and displacing people, animals and property to safe locations, as well as providing them with protection from hazards (Grocki, 2014).

The following study focuses on the evacuation of people from public utility buildings. The analysis is both theoretical and empirical, whereas its main element is the sociological research on the evacuation from university facilities in situation containing a hazard to lives or property, carried out among students of Rzeszow University of Technology. The main research question addressed in the conceptualization phase referred to respondents' knowledge of emergency exits in university buildings and respondents' opinions on evacuation possibilities in the buildings where they attend classes. The research conducted in Rzeszów were preceded by a similar study carried out at I. Horbachevsky Ternopil National Medical University in Ukraine. The comparison of the results provided by both studies may be of great value.

\section{BASIC DEFINITIONS RELEVANT TO EVACUATION OF PEOPLE COMPARED TO DEFINITIONS IN CRISIS MANAGEMENT}

Before one starts to analyze the issue of evacuation from hazardous locations, there is a need to establish the definition of evacuation in the first place. It means that we have to approach the problem from two perspectives: the first one refers to its legal and technical aspects, whereas the second one to social and psychological ones. Therefore, the evacuation from hazardous locations may be analyzed from the perspective of risk management (Gil, 2001; Kaczmarek, 2010).

So what is the actual definition of evacuation? According to paragraph 1 of the Guidelines of the Chief of National Civil Defence of the Act of 17 November 2008 on procedures of evacuation of people, animals and property in case of massive threat, the evacuation is an urgent displacement of people and property away from an area that contains an imminent or ongoing danger to safe locations (Wytyczne, 2008). In fact, most definitions of evacuation mentioned in the Polish academic literature approach this term in a similar way. As an example, the Glossary of Safety Terms describes the evacuation as a planned displacement (removing, taking out, transporting away, bringing out) of people, all sorts of material goods and farm animals from areas or buildings that contain an imminent or ongoing threat of the effects of military actions or disasters, in order to protect, provide assistance (help) and limit material loss (Słownik, 2008). Krzysztof Przeworski, on the other hand, defines evacuation as a planned displacement of people, farm animals and material goods, including removing, taking out, transporting away and bringing them out of areas or buildings that contain an imminent or ongoing threat of the effects of military actions or disasters in order to protect, provide assistance (help) and limit material loss (Przeworski, 2002). According to Joanna Filaber 
evacuation (Lat. evacuatio - emptying, disappearance) is a planned movement of people and property away from a place that contains an ongoing hazard to lives, to a safe location. It is one of the primary actions aimed at providing protection to life and health of people and animals as well as saving material goods, including landmarks and important documentation in case of the occurrence of hazard to lives or property. The evacuation may be carried out in different stages of dangerous occurrences (Filaber, 2015).

\section{Franciszek Mroczko indicates that}

the aim of the evacuation is to protect life and health of people and animals as well as save citizen's property, whereas it may be carried out in various stages of dangerous occurrences. It means that it should be started just after the occurrence of a dangerous situation or in case of an imminent threat - launched as a preemptive strike" (Mroczko, 2012).

According to Patrycja Głogowska, Patrycja Zdrojewska and Hubert Wagner the evacuation is one of the elements of the process of saving people, animals and property from locations that contain an ongoing threat to lives. It is moving people, animals and property away from war or natural disasters-affected areas (Głogowska, Zdrojewska, Wagner, 2016).

One may arrive at a conclusion that the abovementioned definitions include some common elements: evacuation of people, animals and property, planned displacement of people, animals and property, as well as the aim of the evacuation which is protection from danger. What is also common for these definitions is the missing element - they do not mention anything about the preparation of people to emergency situations, i.e. training them how to behave in case of fire, flood or other dangerous situations (Grocki, 2014).

Marek Barć indicates the spatial aspect of the evacuation process, which consists in the movement of people and animals as well as transportation of material goods away from regions that contain and ongoing threat to safer location (Barć, 2017). Joanna Filaber, on the Rother hand, points out the temporal aspect of evacuation, which is carried out among people who have already been injured in a dangerous situation or are at a direct risk of being injured in an ongoing threat of danger. Nevertheless, the evacuation may be preventive, which means that it may be carried out from areas and buildings in case of an imminent incident resulting from the occurrence of various disasters (flood, chemical disaster) or the effects of military actions undertaken during the war (Filaber, 2015).

Definitions of evacuation adopted in countries experiencing a wider variety of emergencies than the ones in Poland take into account other details of this process. National Health Service Organization (NHS) defines evacuation as "removal, from a place of actual or potential danger to a place of relative safety, of people and (where appropriate) other living creatures" (NHS, 2015).

According to the Australian Institute for Disaster Resilience (AIDR)

the evacuation is a risk management strategy that may be used to mitigate the effects of an emergency on a community. It involves the movement of people to a safer location and their return. For an evacuation to be effective it must be appropriately planned and implemented (Emergency, 2018). 
This definition adds the issue of safe locations and indicates the possibility to return to places where the evacuation started after the disappearance of emergency.

Mass Evacuations in Natural Disasters (MEND) informs that the evacuation is the rapid movement of people away from the immediate threat or impact of a disaster to a safer place of shelter. It is commonly characterized by a short time frame, from hours to weeks, within which emergency procedures need to be enacted in order to save lives and minimize exposure to harm (The MEND 2014). Moreover, it may be defined as a

the temporary movement of people to a safer location in order to mitigate the effects of an emergency or disaster on a community" or "the organized, phased, and supervised withdrawal, dispersal, or removal of civilians from dangerous or potentially dangerous areas, and their reception and care in safe areas (The MEND, 2014).

In that case, the definitions include temporal aspects of the evacuation, i.e. evacuation's temporality, time of decision-making process, and, what is more, they mention the care of evacuees.

The evacuation from the incident's area should be carried out in a way that not only allows to displace evacuees from a given place, but also provides them with protection from additional hazards to life and health. Therefore, in order to ensure an effective evacuation and it supervision, it is essential to prepare an appropriate evacuation plan. It needs to specify both the concept of the performance of the evacuation, depending on actual settings, and resources necessary for the accomplishment of this task. The main condition of the effectiveness of the plan is its timeliness, which needs to be verified by a regular stocktaking of resources and analysis of the adopted solutions (Filaber, 2015). Marek Barć additionally indicates that there are three stages of evacuation: a) $1^{\text {st }}$ stage evacuation, which is a rapid movement of people, animals and property away from the immediate unforeseen threat, to a safer place. b) $2^{\text {nd }}$ stage evacuation, which is a previously planned movement of people, animals and property from areas adjacent to plants, hydraulic structures, flood zones or other buildings that present potential risk in case they are damaged or experience a fatal breakdown, c) $3^{\text {rd }}$ stage evacuation, which is a previously prepared movement of people, animals and property in case of an increased defence readiness of a state and the occurrence of any threat to the state security or war (Barć, 2017).

The MEND Guide names the following types of evacuation (The MEND, 2014):

1. Mandatory - an evacuation ordered and directed by authorities when it is judged that the risk to a population is too great to allow them to remain where they are, and where sheltering in place would likely entail a higher level of risk. This places a duty of responsibility on authorities to ensure that people have the information and assistance needed for safe and timely evacuation and that evacuees are cared for.

2. Advised - an official evacuation advisory message may be issued to enable early response and informed decision-making by the population at risk on whether and when to evacuate. An advisory may precede a mandatory order to evacuate as the level of the threat and the risk associated with the alternative of sheltering in place increases.

3. Spontaneous - when people evacuate their current location due to actual or perceived risk using their own means (self-evacuation) and without (or before) being officially 
advised or directed to do so. This may include people who leave areas outside a designated evacuation zone (also known as "shadow" evacuations).

4. Mass - it implies the evacuation of whole communities, neighborhoods or geographical areas. The scale and complexity of such evacuations creates the potential for emergency response capacity in a given jurisdiction or country to be overwhelmed and the necessity for coordination across one or more jurisdictions to effect the evacuation and sheltering of evacuees.

One may also mention self-evacuation, in which case, a person may evacuate a hazardous location, before being officially advised or ordered to, by using their own means to take with them not only their family members, but also property, and return to places where the evacuation started after the disappearance of emergency. Such evacuees may use their own means of transport or off-road vehicles, heavy goods vehicles, buses, ships, houseboats, boats or even planes. There is also a group of people with critical transportation needs, who do not have access to any means of transport, live far away from other people or have lost the ability to self-evacuate as a result of the occurrence of the hazardous event. They need special assistance in leaving the location affected by a disaster, provided by specialized institutions or services, including military, fire department or civil defence (Planning, 2019).

Magdalena Masłowska-Szczerba proposes a different classification of evacuation, in which she differentiates evacuation of people and evacuation of property. This classification method addresses five types of evacuation and evacuees' behaviour, including (Masłowska-Szczerba, 2015):

1. In case of evacuation of people: a) spreading, i.e. self-evacuation from areas with dense population to self-chosen locations, that happens before being officially advised or ordered to evacuate, or at the initial phase of evacuation process, b) dispersion, i.e. a planned movement of people to locations advised by the civil defence services, with the use of own or public means of transport, c) withdrawal, i.e. movement of people during military action or natural disasters organized by the military or rescue operation's leaders, sometimes referring only to specific groups of civilians, d) evacuation transfer, i.e. movement of people across the evacuation area in search of a temporary shelter or food or drinking water supplies, or fuel, e) anarchic evacuation, i.e. emergency escape of people unfamiliar with any rules of planned movement of people or resistant to act according to them.

2. In case of evacuation of people: a) spreading, i.e. movement of valuable property at risk of damage to chosen safe locations in a given area by staff members responsible for its evacuation, $b$ ) dispersion, i.e. movement of property away from the hazardous site to previously chosen and prepared locations in a given area, c) withdrawal, i.e. transportation of movable property out of the evacuation zone, organized by the military leaders in case of military actions, war, rescue operations during flood, fire, construction disaster, or other occurrences threatening the peace, d) evacuation transfer, i.e. transportation of property across the evacuation in order to place it in a temporary shelter, e) anarchic evacuation, i.e. spontaneous throwing out of property through the windows of a building, moving in case of emergency situation out of the building area, without any previously prepared plan or against its guidelines.

The evacuation should also include transportation of animals from the danger zones. It refers to service animals, assisting animals, pets, working dogs, as well as livestock. 
Moreover, one should also take into account the evacuation of wild animals, exotic animals, zoo animals, laboratory animals, animals from shelters and breeding animals. When it comes to service animals, they are evacuated with together their owners, whereas animals assisting blind persons are evacuated together with their owners and placed in locations dedicated for people. Other animals ought to be evacuated to safe locations, away from the danger zones (Planning, 2019).

Franciszek Mroczko points out that,

unprepared and chaotically conducted evacuation may do more harm than good. It may happen that the evacuation turns out to be the most effective way to save life and it has to be undertaken without regard to dangers and inconveniences resulting from it. Nevertheless, when ordering an evacuation one has to apply the voluntary principle. It is the citizen who decides if they want to evacuate or not. They can only take the right decision if they are appropriately trained and informed about the type and level of danger, its potential effects, appropriate manners, etc. Regardless of the citizen's decision, rescue services are no allowed to leave them unattended (Mroczko, 2012).

The process of planning and organizing an evacuation needs to specify the sequence in which people are evacuated, starting with mothers with children, pregnant women, people with disabilities, people form health care centers, children from orphanages, chronic and terminally ill patients from hospitals, patients from nursing homes as well as the elderly and the infirm (Filaber, 2015). Therefore, it is essential to create an evacuation plan for the most vulnerable and unable to handle emergency situations on their own, due to their physical and psychological limitations. Such groups include among others (Pałubicka-Florczak, Borucka, 2010):

1. Priority 1 goes to people with sight impairment who a) have a developed spatial memory of the immediate surrounding and when hearing the announcement of the evacuation they are prone to follow the route that they are familiar with, which may lead them to the source of danger. That is why, they should be assigned with a person that would take care of them and take them to a safe location, b) get disoriented easily and tend to panic, c) do not see hazard zones, including dangling electrical wires and construction elements that they may hit and thus make the evacuation impossible, d) are unable to get to the assembly points alone if being forced to leave the hazard zone.

2. Priority 2 goes to people with speech and hearing impairment who: a) have not developed spatial imagination, b) are able to head to assembly points that are precisely marked by visible escape routes.

3. Priority 3 goes to children and the youths who a) due to being emotionally immature may create a risk for extremely different patterns of behaviour in case of emergency, including, among others, insubordination, hiding or running away from the educator, b) should be prepared and trained in an entertaining way, in order to become familiar with evacuation procedures used in case of emergency.

The evacuation is a comprehensive and complicated task. Nevertheless, it has to become subject of research, especially when taking into account the fact that society has not developed sufficient habits necessary for leaving quickly emergency sites, both in open areas, the ones with limited access, as well as in buildings. 
Another issue is the evacuation of people from sites seized with fire, regardless of whether it refers to a burning building or fire in the forest, grass or other open space area (Brushlinsky, Sokolov, Wagner, 2010).

Nikolay Bruschlinsky, Sergei Sokolov and Peter Wagner claim that, "a fire is an uncontrolled process of burning, which is harmful both the society and the environment" (Bruschlinsky, Sokolov, Wagner, 2016). Tomasz Sawicki defines fire as an uncontrolled spreading of fire dangerous both for people and buildings, whereas its conditions include: a) combustible material, b) oxidant, c) heat, d) necessary chain reactions (Sawicki, 2008). Mirosław Kosiorek, on the other hand, indicates that,

a fire is a thermal decomposition of combustible materials impossible to be controlled in time and space. Basic physic-chemical process occurring during the fire is fast oxidation, which generates great amount of heat. The impact of a fire on a building is an accidental action (Kosiorek, 2015).

In case of fire the risk factors include: a) increased temperature and heat flux density, b) toxic combustion products, c) smoke, d) lack of oxygen, e) damage of the building construction or its elements (Sawicki, 2004).

Next to the definition of a fire, the professional literature mentions also: a) fire hazard, which refers to the risk of an uncontrolled burning process, i.e. fire causing damage in society, environment and the protected site, b) the risk of fire, i.e. a quantitative analysis of the possibility of fire hazards and its effects, using relevant physio-chemical parameters, c) managing the risk of fire, i.e. the development and implementation of system of measures (engineering, economic, social and others) that reduce the risk of fire to an acceptable level, d) fire safety, i.e. the level of protection of a facility against fire, in which case the total risk of fire does not exceed relevant critical values (Bruschlinsky, Sokolov, Wagner, 2016).

Among specific characteristics of a fire there are: a) in most cases (except for secondary effects of atmospheric and seismic phenomena) fire is caused by human activity, b) it does not produce direct mechanical effects, but brings about changes in the environment of a building and its surrounding, whereas mechanical effects on the building's construction are secondary. Thus, a fire triggers changes in: a) thermal conditions, b) pressure, c) the chemical composition of the atmosphere (decreasing the oxygen level and combustion products toxicity), d) visibility (smoke). The abovementioned factors influence users and construction of a building, as well as its entire surrounding. There is also a possibility that a fire results in a serious environmental contamination. In such case, the environmental situation in various areas, building parts and premises is changed. This state depends on a number of factors, such as: a) the ability of a structure to transmit loads in conditions of major thermal impact, b) properties of building envelopes, c) spatial planning solutions, d) type and number of stored combustible materials, e) type and distribution of building materials, f) installations in a building used to extinguish fire (fire-extinguishing systems) and reduce spread of smoke (fire ventilation) (Kosiorek, 2015).

It is worth mentioning that the phenomena occurring during fire indoors include mainly heat and mass transfer between the fuel and the surrounding. An indoor fire may spread in various ways, depending on the room geometry, its ventilation and type of fuel engaged in the burning process. The development process of indoor fire starts from the ignition of combustible materials that generates a great amount of energy as a result of a spreading fire. During that stage, fire is controlled mainly by fuel, and the burning process produces not 
only energy, but also toxic combustion products. Hot fire gases are surrounded by cold air, which, as a result of density differences between hot fire gases and the air, gives rise to a convection column transporting combustion products in the direction of a room's ceiling. The fire convection column leads to the creation of a layer of hot fire gases and their spread in the entire room. Within this stage, the physical phenomena occurring in the hot fire gases layer near the ceiling include mainly the formation of heat fluxes with large temperature gradients, which have a thermal effect on building's construction and chemical phenomena, including the formation of various toxic compounds harmful for the human body (Porowski, 2016).

There are three main stages of an indoor fire (Porowski, 2016):

1. $1^{\text {st }}$ stage: The development of fire (the so called pre-flashover stage). It is characterized by a low average temperature and a relatively slow pace of development, depending mainly on the reaction to fire of materials directly in contact with the source of fire. From the moment of ignition, the burning material heats the nearest surrounding, which results in spread of fire. The process of burning produces more and more hot combustion products filling a room.

2. $2^{\text {nd }}$ stage: Fully developed (the so called post-flashover stage). During that stage a fire is engulfing all of its available fuel sources and the entire room is filled with flames.

3. $3^{\text {rd }}$ stage: Decay. It starts when temperature of fire drops to $80 \%$ of the peak burning temperature.

The process of transition from the development stage of fire to the fully developed fire is called a flashover. The development of an indoor fire and its relevant parameters typical for a given fire scenario, depend on many factors, such as: a) place of the occurrence of fire in respect of distribution of combustible materials in a room, b) type and amount of combustible materials in a room, c) possible chemical reactions between the materials in case their packaging are damaged in course of fire, d) placement of combustible materials in relation to walls, ceilings, etc. e) possibilities of oxygen supply, f) presence and effectiveness of fire-extinguishing equipment and fire-extinguishers, g) changes in burning properties of materials as a result of aging, h) other factors (Porowski, 2016).

To sum up, the evacuation from hazardous sites is a complicated process, therefore, it is not only essential to train the appropriate behaviour patterns in emergency situations, but also to introduce preventive measures.

\section{METHODOLOGICAL APPROACH AND CHARACTERISTICS OF THE STUDY POPULATION}

The study was conducted from January 2018 to March 2018 in the form of an auditorium questionnaire, among first-year students in selected departments of Rzeszow University of Technology. A similar study has been prepared at I. Horbachevsky Ternopil National Medical University in Ukraine.

The respondents of the study were students of the following fields of study: Internal Security at the Faculty of Management, Transport at the Faculty of Mechanical Engineering and Aeronautics, Computer Engineering at the Faculty of Electrical and Computer Engineering. In the end, 252 questionnaires were analyzed (Greń, 1975). From a methodological point of view, the maximum percentage error accounted for $5.0 \%$ for a 0,95 confidence level (Szreder, 2004). The study was supposed to provide information 
about respondents knowledge of emergency exits in the buildings and possibilities of evacuation from the university facilities. It is worth mentioning that the statistical data was collected with the use of Statistica programme, whereas the analytical procedure consisted first of all in coding of the received survey questionnaires and then generating statistical data in Statistica, which calculated the correlation between quantitative traits, using chisquare independence test and Pearson correlation coefficient. The following study refers to a study carried out in 2015 by Artur Woźny, Piotr Saja, Magdalena Dobosz, Andrzej Pacana, Marcin Zawada (Woźny, Saja, Dobosz, Pacana, Zawada, 2016).

The main research hypothesis of the study is: respondents knowledge of emergency exits in the buildings and possibilities of evacuation from the university facilities is very limited.

The characteristic of the population included in the study was limited to three independent variables: age, sex and place of residence. The distribution in respect of respondents personal data is presented in the tables.

The first analyzed variable is age of the respondents. It is presented in Table 1.

Table 1. Respondents' age

\begin{tabular}{|l|c|c|}
\hline \multicolumn{1}{|c|}{ Specification } & Frequency & \% \\
\hline Up to 21 years & 183 & 72.6 \\
\hline 22 and above & 69 & 27.4 \\
\hline Total & 252 & 100.0 \\
\hline
\end{tabular}

The data show that $72.6 \%$ of respondents are up to 21 years old, whereas $27.4 \%$ are 22 and above. Therefore, they are students of the early years of studies, who, however, already have some knowledge about appropriate behaviour patterns in emergency situations, and know how to move around given university buildings.

Another variable is sex of the respondents. It is presented in Table 2.

Table 2. Respondents' sex

\begin{tabular}{|l|c|c|}
\hline \multicolumn{1}{|c|}{ Specification } & Frequency & \% \\
\hline Female & 101 & 40.1 \\
\hline Male & 151 & 59.9 \\
\hline Total & 252 & 100.0 \\
\hline
\end{tabular}

According to the data presented in Table 2, women accounted for $40.1 \%$ of the respondents, whereas men for $59.9 \%$. The lack of balance between men and women results from the fact that technical universities, in comparison to other types of universities, are dominated by men, with the exception of the Faculty of Management, where the percentage of female students is the biggest of all faculties.

The last analyzed variable is place of residence of respondents. It is presented in Table 3. 
Table 3. Respondents' place of residence

\begin{tabular}{|l|c|c|}
\hline \multicolumn{1}{|c|}{ Specification } & Frequency & \% \\
\hline Urban Area & 104 & 41.3 \\
\hline Rural Area & 148 & 58.7 \\
\hline Total & 252 & 100.0 \\
\hline
\end{tabular}

The analysis of the data shows that $41.3 \%$ respondents declare that they live in the city, whereas $58.7 \%$ in the country. This results is also understandable due to the fact that most students of Rzeszow University of Technology are from the broadly understood Podkarpackie region, which is characterized by a large rural population.

\section{STUDENTS OF THE RZESZOW UNIVERSITY OF TECHNOLOGY AND EVACUATION FROM PUBLIC UTILITY BUILDINGS}

At the beginning, the respondents were asked if they are able to give the location of emergency exits and if they know how to behave if the fire alarm goes off in a building where they currently are. Table 4 presents the distribution of answers to the abovementioned questions.

Table 4. Respondents' knowledge of emergency exits and proper behaviour in case of fire alarm

\begin{tabular}{|l|c|c|}
\hline \multicolumn{1}{|c|}{ Specification } & Frequency & $(\boldsymbol{\%})$ \\
\hline Strongly Agree & 55 & 21.8 \\
\hline Rather Agree & 159 & 63.1 \\
\hline Rather Disagree & 23 & 9.1 \\
\hline Strongly Disagree & 2 & 0.8 \\
\hline Neutral & 13 & 5.2 \\
\hline Total & 252 & 100.0 \\
\hline
\end{tabular}

According to the data, $84.9 \%$ respondents (Strongly Agree and Rather Agree altogether) have considerable knowledge of the location of emergency exits and proper behaviour in case of fire alarm going off, whereas $10.0 \%$ respondents (Strongly Disagree and Rather Disagree) do not have it. 5.2\% has no opinion on that matter. Therefore, one may get to the conclusion, that the vast majority of respondents is convinced that their knowledge of the evacuation procedures in a given building is satisfactory, whereas $10 \%$ respondents admits that their knowledge on that is very limited. Nevertheless, the greatest paradox is the fact, that the respondents admitted in the discussion with the interviewer that, first of all, they have never experienced an emergency situation forcing them to evacuate from a university building, and, moreover, evacuation plans are available on each building floor, so in case of emergency situation they can always familiarize themselves with them. When the interviewer asked them, if they do not think that it might be too late to get to know the emergency routes, they claimed, that they will run in the same direction as everyone else. 
In order to establish the correlation between the dependent and independent variables, they were compared with each other. Considering the limitations of the paper's length, the abovementioned variables are presented in a condensed form. Therefore, we may conclude that no independent variables have in any way influenced the fact that the respondents have considerable or limited knowledge of emergency exits or behaviour patterns in case of a fire alarm ${ }^{5}$.

Another question asked by the interviewer was about the emergency exit signs, i.e. if the emergency route signs are legible and clear, and if there are fire-extinguishers in university facilities. Distribution of the answers is presented in Table 5.

Table 5. Respondents' opinion that a given university building has legible and clear emergency route signs, as well as fire-extinguishers

\begin{tabular}{|l|c|c|}
\hline \multicolumn{1}{|c|}{ Specification } & Frequency & $(\boldsymbol{\%})$ \\
\hline Strongly Agree & 96 & 38.1 \\
\hline Rather Agree & 141 & 56.0 \\
\hline Rather Disagree & 5 & 2.0 \\
\hline Strongly Disagree & 0 & 0.0 \\
\hline Neutral & 10 & 4.0 \\
\hline Total & 252 & 100.0 \\
\hline
\end{tabular}

As the study shows, $94.1 \%$ respondents is convinced that a given university building has legible and clear emergency route signs, as well as fire-extinguishers (Strongly Agree and Rather Agree altogether), whereas only $2.0 \%$ is of the opinion that they do not have indepth knowledge on that (Strongly Disagree and Rather Disagree altogether), and 4.0\% respondents stays neutral. The distribution of answers contains a very positive information, that the emergency route signs are in the buildings and moreover they are placed in clearly visible locations. Similarly to the previous question, the dependent variable was compared with independent variables. The analysis indicates that no independent variables have in any way influences the fact that the respondents are convinced that a given university building has legible and clear emergency route signs, as well as fire-extinguishers ${ }^{6}$.

The next question that the responders were to answer was about their opinion on the statement that a given university building has emergency exit signs that are clear and unambiguous. The distribution of the answers is presented in Table 6.

The presented data show that $90.1 \%$ respondents is of the opinion that a given university building has clear and unambiguous emergency exit signs (Strongly Agree and Rather Agree altogether), only 3.2\% thinks the opposite (Strongly Disagree and Rather Disagree

\footnotetext{
5 Age: $\left(\chi^{2}\right)=5.166748826$, (number of degrees of freedom $(1 \mathrm{ss})=4$, statistical significance $($ pi $)=0.05)$. Probability Distribution $(\operatorname{Pr})=0.270611928$. No correlation. Sex: $\left(\chi^{2}\right)=3.945848291$, (lss $=4$, pi $=0.05)$. $\operatorname{Pr}=0.413384091$. No correlation. Place of residence: $\left(\chi^{2}\right)=4.205084443$, (lss $=4$, pi $=0.05) . \operatorname{Pr}=0.378961609$. No correlation.

6 Age: $\left(\chi^{2}\right)=1.480487102$, $(\mathrm{lss}=3$, pi $=0.05)$. $\operatorname{Pr}=0.686781164$. No correlation. Sex: $\left(\chi^{2}\right)=3.673632563$, (lss $=3$, pi $\left.=0.05\right) . \operatorname{Pr}=0.298930888$. No correlation. Place of residence: $\left(\chi^{2}\right)=1.12096046,(\mathrm{lss}=3$, pi $=0.05)$. $\operatorname{Pr}=0.773201676$. No correlation.
} 
altogether) and $6.7 \%$ has no opinion on that matter. It is a very positive result due to the fact that it proves that the university buildings are properly marked. As in case of the previous question, the dependent variable was compared with independent variables. The analysis indicates that only the place of residence variable influences respondents' opinion that a given university building has clear and unambiguous emergency exit signs. It means, that more students living in a city, in comparison to students living in a country, is of the opinion that a given university building has clear and unambiguous emergency exit signs. The remaining variables do not have any impact on that opinion ${ }^{7}$.

Table 6. Respondent's opinion that a given university building has clear and unambiguous emergency exit signs

\begin{tabular}{|l|c|c|}
\hline \multicolumn{1}{|c|}{ Specification } & Frequency & $(\boldsymbol{\%})$ \\
\hline Strongly Agree & 77 & 30.6 \\
\hline Rather Agree & 150 & 59.5 \\
\hline Rather Disagree & 8 & 3.2 \\
\hline Strongly Disagree & 0 & 0.0 \\
\hline Neutral & 17 & 6.7 \\
\hline Total & 252 & 100.0 \\
\hline
\end{tabular}

Last but not least, the respondents had to say if they have ever participated in any evacuation drills in a given university building, OHS training on recognizing alarm signals and using fire-extinguishers conducted by experts. Distribution of the answers is presented in Table 7.

Table 7. Respondents' participation in evacuation drills in a given university building, OHS training on recognizing alarm signals and using fire-extinguishers conducted by experts

\begin{tabular}{|l|c|c|}
\hline \multicolumn{1}{|c|}{ Specification } & Frequency & $(\boldsymbol{\%})$ \\
\hline Strongly Agree & 96 & 38.1 \\
\hline Rather Agree & 54 & 21.4 \\
\hline Rather Disagree & 31 & 12.3 \\
\hline Strongly Disagree & 61 & 24.2 \\
\hline Neutral & 4 & 4.0 \\
\hline Total & 252 & 100.0 \\
\hline
\end{tabular}

\footnotetext{
7 Age: $\left(\chi^{2}\right)=1.61579301,(1 \mathrm{ss}=3, \mathrm{pi}=0.05) . \operatorname{Pr}=0.675814143$. No correlation. Sex: $\left(\chi^{2}\right)=$ $=4.081548253,(\mathrm{lss}=3$, pi $=0.05) . \operatorname{Pr}=0.252791967$. No correlation. Place of residence: $\left(\chi^{2}\right)=7.846846921,(\mathrm{lss}=3, \mathrm{pi}=0.05) . \operatorname{Pr}=0.049285266$. There is a correlation between the dependent variable and place of residence. Pearson correlation coefficient $=0.220929466$, low correlation.
} 
When analyzing the results, 59.5\% respondents have participated in evacuation drills in a given university building as well as OHS training on recognizing alarm signals and using fire-extinguishers conducted by experts (Strongly Agree and Rather Agree altogether), whereas $36.5 \%$ has never taken part in such trainings (Strongly Disagree and Rather Disagree altogether), and $4.0 \%$ has no opinion on that subject. In order to find a correlation between the dependent variable and independent variables, they were compared with each other. As the study shows, no independent variables have in any way influenced the fact that the respondents participated in evacuation drills in a given university building as well as OHS training on recognizing alarm signals and using fire-extinguishers conducted by experts ${ }^{8}$.

One of the next questions was about the knowledge of assembly points in case of emergency. Distribution of the answers is presented in Table 8.

Table 8. Respondents' knowledge of assembly points in case of emergency

\begin{tabular}{|l|c|c|}
\hline \multicolumn{1}{|c|}{ Specification } & Frequency & $(\boldsymbol{\%})$ \\
\hline Strongly Agree & 9 & 3.6 \\
\hline Rather Agree & 52 & 20.6 \\
\hline Rather Disagree & 71 & 28.2 \\
\hline Strongly Disagree & 55 & 21.8 \\
\hline Neutral & 65 & 25.8 \\
\hline Total & 252 & 100.0 \\
\hline
\end{tabular}

The data presented above show that $24.2 \%$ respondents have some knowledge of assembly points in case of emergency situation (Strongly Agree and Rather Agree altogether), whereas $50.0 \%$ do not have such knowledge (Strongly Disagree and Rather Disagree). $25.8 \%$ responding students do not have opinion on this matter. The dependent variable was put together with independent variables in order to find a clear collocation. It was observed that no independent variables have in any way influenced the fact that the respondents have knowledge of assembly points in case of emergency situation ${ }^{9}$.

The respondents were also asked about the ways of cutting off electricity and gas supplies in a given university building. Table 9 presents distribution of the answers.

\footnotetext{
${ }^{8}$ Age: $\left(\chi^{2}\right)=4.318647131$, $(\mathrm{lss}=4$, pi $=0.05) . \operatorname{Pr}=0.364595914$. No correlation. Sex: $\left(\chi^{2}\right)=2.991840835$, (lss $\left.=4, \mathrm{pi}=0.05\right) . \operatorname{Pr}=0.559191744$. No correlation. Place of residence: $\left(\chi^{2}\right)=4.458741594,(\mathrm{lss}=4$, pi $=0.05)$. $\operatorname{Pr}=0.347467731$. No correlation.

9 Age: $\left(\chi^{2}\right)=4.978598589$, $($ lss $=4$, pi $=0.05)$. $\operatorname{Pr}=0.289500471$. No correlation. Sex: $\left(\chi^{2}\right)=$ $=6.937190431$, $(\mathrm{lss}=4, \mathrm{pi}=0.05) . \operatorname{Pr}=0.139244886$. No correlation. Place of residence: $\left(\chi^{2}\right)=3.640024819,(\mathrm{lss}=4, \mathrm{pi}=0.05) . \operatorname{Pr}=0.456908958$. No correlation.
} 
Table 9. Respondents' knowledge of a way of cutting off electricity and gas supplies in a given university building

\begin{tabular}{|l|c|c|}
\hline \multicolumn{1}{|c|}{ Specification } & Frequency & $(\boldsymbol{\%})$ \\
\hline Strongly Agree & 8 & 3.2 \\
\hline Rather Agree & 27 & 10.7 \\
\hline Rather Disagree & 79 & 31.3 \\
\hline Strongly Disagree & 133 & 52.8 \\
\hline Neutral & 5 & 2.0 \\
\hline Total & 249 & 100.0 \\
\hline
\end{tabular}

The analysis of the received results allows to get to a conclusion that $13.9 \%$ respondents knows how to cut off electricity and gas supplies in a given university building (Strongly Agree and Rather Agree altogether), 84.1\% do not have that kind of knowledge (Strongly Disagree and Rather Disagree altogether), and 2.0\% remains neutral. The dependent variable was compared with independent variables, and it was concluded, that no independent variables have in any way influenced respondents' knowledge of ways of cutting off electricity and gas supplies in a given university building ${ }^{10}$.

The last question addressed to the respondents was if they have ever read the procedure for handling emergencies issued by the Crisis Management Center. Table 10 presents distribution of the answers.

Table 10. Respondents' familiarization with the procedure for handling emergencies issued by the Crisis Management Center

\begin{tabular}{|l|c|c|}
\hline \multicolumn{1}{|c|}{ Specification } & Frequency & $(\boldsymbol{\%})$ \\
\hline Strongly Agree & 26 & 10.3 \\
\hline Rather Agree & 71 & 28.2 \\
\hline Rather Disagree & 85 & 33.7 \\
\hline Strongly Disagree & 58 & 23.0 \\
\hline Neutral & 12 & 4.8 \\
\hline Total & 249 & 100.0 \\
\hline
\end{tabular}

As can be seen from the data presented above $38.5 \%$ respondents have read the procedure for handling emergencies issued by the Crisis Management Center (Strongly Agree and Rather Agree altogether), 56.7\%, however, did not have the opportunity to become familiarized with it (Strongly Disagree and Rather Disagree altogether). 4.8\% respondents do not have any opinion on this matter. The comparison of the dependent

${ }^{10}$ Age: $\left(\chi^{2}\right)=4.60070763$, (lss $=4$, pi $\left.=0.05\right) . \operatorname{Pr}=0.330772604$. No correlation. Sex $\left(\chi^{2}\right)=$ $=4.651008252,(\mathrm{lss}=4$, pi $=0.05) . \operatorname{Pr}=0.325015357$. No correlation. Place of residence: $\left(\chi^{2}\right)=1.613004238,(\mathrm{lss}=4, \mathrm{pi}=0.05)$. $\operatorname{Pr}=0.806452988$. No correlation. 
variable and independent variables has shown, that no independent variables have in any way influenced respondents' familiarization with the procedure for handling emergencies issued by the Crisis Management Center ${ }^{11}$.

\section{CONCLUSIONS}

When summarizing the discussion on emergency evacuations we need to indicate that the study described in the following paper referred to evacuation in narrow terms, i.e. movement of evacuees from burning buildings. The study has shown that the hypothesis that respondents' knowledge of emergency exits in the university buildings and possibilities of evacuation from the university facilities, is very limited, has been confirmed. Therefore, the respondents claim that they know where the evacuation exits are located and how to behave in case of fire alarm in a university building where they currently are, but they are not able to express that knowledge clearly. They point out, however, that the emergency route signs are legible, clear and unambiguous. According to the research, not every respondent had an opportunity to participate in any evacuation drills in a given university building, OHS training on recognizing alarm signals and using fire-extinguishers conducted by experts, which is not a very positive information. Moreover, knowledge of assembly points in case of emergency, similarly to knowledge of ways of cutting off electricity and gas supplies in a given university building, is very limited. The same refers to respondents' familiarization with the procedure for handling emergencies issued by the Crisis Management Center.

The following study leads to the conclusion that knowledge of evacuation in a narrow sense, is currently on a very low level, which definitely means, that knowledge of any type of evacuation from hazardous sites is also very limited. It is a very pessimistic observation resulting from the following study.

One may only hope that there will be no need for evacuating students from university buildings and, what is more, relevant services are well prepared for every possible emergency situation occurring in university buildings.

\section{REFERENCES}

Barć, M. (2017). Zarządzanie ewakuacją ludności i mienia podczas zagrożeń niemilitarnych przez oddziały $i$ pododdziały sit zbrojnych RP. „Roczniki Ekonomii i Zarzqdzania”, 9th Volume (45). No. 2.

Brushlinsky, N., Sokolov, S., Wagner, P. (2010). Humanity and Fires. Warszawa: Fundacja Edukacja i Technika Ratownictwa.

Brushlinsky, N., Sokolov, S., Wagner, P. (2016). Ryzyko pożarowe i zapobieganie pożarom dzisiaj i prognozy na przyszłość [In:] Guzewski, P., Wróblewski, D., Małozięć, D., ed., Czerwona księga pożarów. Wybrane problemy pożarów oraz ich skutków. 2nd Volume. Józefów: Wydawnictwo Centrum Naukowo-Badawcze Ochrony Przeciwpożarowej im. Józefa Tuliszkowskiego - Państwowy Instytut Badawczy.

Emergency Evacuation Framework. (2018). Department of Police. Fire and Emergency Management, Tasmanian Government, Hobart.

\footnotetext{
11 Age: $\left(\chi^{2}\right)=1.262252726$, $($ lss $=4, \mathrm{pi}=0.05) . \operatorname{Pr}=0.867746579$. No correlation. Sex: $\left(\chi^{2}\right)=$ $=8.76314477,(1 \mathrm{ss}=4, \mathrm{pi}=0,05) . \operatorname{Pr}=0.06730021$. No correlation. Place of residence: $\left(\chi^{2}\right)=$ $=5.858889438,(\mathrm{lss}=4, \mathrm{pi}=0.05) . \operatorname{Pr}=0.209937251$. No correlation.
} 
Filaber, J. (2015). Ewakuacja osób niepełnosprawnych w sytuacji kryzysowej [In:] Giełda, M., Raszewska-Skałecka, R., ed., Prawno-administracyjne aspekty sytuacji osób niepetnosprawnych w Polsce. Prace Naukowe Uniwersytetu Wrocławskiego. Wrocław: E-Wydawnictwo.

Gil, Z. (2001). Zarządzanie ryzykiem i antyryzykiem $w$ działalności gospodarczej i społecznej. Kraków: Wydawnictwo Naukowo-Dydaktyczne Akademii Górniczo-Hutniczej im. Stanisława Staszica.

Głogowska, P., Zdrojewska, P., Wagner, H. (2016). Ewakuacja i jej aspekty w ujęciu teoretycznym. „Zeszyty Naukowe Ruchu Studenckiego”, No. 1.

Greń, J. (1975). Statystyka matematyczna. Modele i zadania. Warszawa: PWN.

Grocki, R. (2014). Osoby niepetnosprawne w sytuacji zagrożenia. Warszawa: Difin.

Kaczmarek, T. T. (2010). Zarządzanie ryzykiem. Ujęcie interdyscyplinarne. Warszawa: Difin.

Kosiorek, M. (2015). Ochrona przeciwpożarowa. Oddziaływania pożaru na użytkowników $i$ konstrukcję. Part 1. Builder. No. 10.

Masłowska-Szczerba, M. (2015). Ewakuacja - pojęcie, zasady i podstawy prawne. „Ostry Dyzur”, 8th Volume. No. 2 (38).

Mroczko, F. (2012). Zarzązanie kryzysowe w sytuacjach zagrożeń niemilitarnych. Zarys problemów regionu dolnośląskiego. Wałbrzych: Wałbrzyska Wyższa Szkoła Zarządzania i Przedsiębiorczości.

NHS England Emergency Preparedness. Resilience and Response (EPRR). Planning for the Shelter and Evacuation of People in Healthcare Settings. (2015). Prescot: Mersey Care NHS Fundation Trust.

Pałubicka-Florczak, E., Borucka, A. (2010). Ewakuacja obiektów oświatowych: procedury, zadania oraz ćwiczenia ewakuacyjne. Poznań: Komenda Wojewódzka Państwowej Straży Pożarnej w Poznaniu.

Planning Considerations. Evacuation and Shelter-in-Place Guidance for State. Local. Tribal and Territorial Partners. (2019). New York: Department of Homeland Security. US Federal Emergency Management Agency.

Porowski, R. (2016). Naukowe metody wspomagajace proces ustalania przyczyn powstawania pożarów [In:] Guzewski, P., Wróblewski, D., Małozięć, D. (ed.), Czerwona księga pożarów. Wybrane problemy pożarów oraz ich skutków. 2nd Volume. Józefów: Wydawnictwo Centrum Naukowo-Badawcze Ochrony Przeciwpożarowej im. Józefa Tuliszkowskiego - Państwowy Instytut Badawczy.

Przeworski, K. (2002). Ewakuacja jako sposób ochrony ludności. Warszawa: Wydawnictwo Akademii Obrony Narodowej.

Sawicki, T. (2008). Badanie przyczyn pożarów. Mini słownik. Katowice: Wydawnictwo Elamed. Katowice.

Sawicki, T. (2004). Czynniki zagrażające bezpieczeństwu strażaków w warunkach pożaru. „Bezpieczeństwo Pracy”, Nr 7-8.

Stownik terminów z zakresu bezpieczeństwa (2008). Warszawa: Wydawnictwo Akademii Obrony Narodowej.

Szreder, M. (2004). Metody i techniki sondażowych badań opinii. Warszawa: PWE.

The MEND Guide. Comprehensive Guide for Planning Mass Evacuations in Natural Disasters. Pilot Document. (2014). London: Global Camp Coordination and Camp Management (CCCM) Cluster. 
Woźny, A., Saja, P., Dobosz, M., Pacana, A., Zawada, M. (2016). Zarzqdzanie bezpieczeństwem w sytuacjach kryzysowych na przykładzie próbnych ewakuacji w placówkach oświatowych. „Zeszyty Naukowe Politechniki Poznańskiej. Organizacja i Zarządzanie”, $\mathrm{Nr} 71$.

Wróblewski, D., ed. (2015). Zarządzanie ryzykiem. Przegląd wybranych stanowisk. Józefów: Centrum Naukowo-Badawcze Ochrony Przeciwpożarowej im. Józefa Tuliszkowskiego. Państwowy Instytut Badawczy.

Guidelines of the Chief of National Civil Defence of the Act of 17 November 2008 on procedures of evacuation of people, animals and property in case of massive threat.

DOI: $10.7862 /$ rz.2021.hss.15

The text was submitted to the editorial office: July 2020.

The text was accepted for publication: June 2021. 
